\title{
The Ethylene Responsive Factor Required for Nodulation 1 (ERN1) Transcription Factor Is Required for Infection-Thread Formation in Lotus japonicus
}

\author{
Yasuyuki Kawaharada, ${ }^{1}$ Euan K. James, ${ }^{2}$ Simon Kelly, ${ }^{1}$ Niels Sandal, ${ }^{1}$ and Jens Stougaard ${ }^{1}$ \\ ${ }^{1}$ Centre for Carbohydrate Recognition and Signalling, Department of Molecular Biology and Genetics, Aarhus University, \\ Gustav Wieds Vej 10, DK-8000 Aarhus C, Denmark; and ${ }^{2}$ The James Hutton Institute, Invergowrie, Dundee DD2 5DA, U.K. \\ Accepted 5 January 2017.
}

\begin{abstract}
Several hundred genes are transcriptionally regulated during infection-thread formation and development of nitrogen-fixing root nodules. We have characterized a set of Lotus japonicus mutants impaired in root-nodule formation and found that the causative gene, Ern1, encodes a protein with a characteristic APETALA2/Ethylene Responsive Factor (AP2/ERF) transcriptionfactor domain. Phenotypic characterization of four ern1 alleles shows that infection pockets are formed but root-hair infection threads are absent. Formation of root-nodule primordia is delayed and no normal transcellular infection threads are found in the infected nodules. Corroborating the role of ERN1 (ERF Required for Nodulation1) in nodule organogenesis, spontaneous nodulation induced by an autoactive CCaMK and cytokinininduced nodule primordia were not observed in ern1 mutants. Expression of Ern1 is induced in the susceptible zone by Nod factor treatment or rhizobial inoculation. At the cellular level, the pErn1:GUS reporter is highly expressed in root epidermal cells of the susceptible zone and in the cortical cells that form nodule primordia. The genetic regulation of this cellular expression pattern was further investigated in symbiotic mutants. Nod factor induction of Ern1 in epidermal cells was found to depend on Nfr1, Cyclops, and Nsp2 but was independent of Nin and Nf-yal. These results suggest that ERN1 functions as a transcriptional regulator involved in the formation of infection threads and development of nodule primordia and may coordinate these two processes.
\end{abstract}

Development of legume root nodules hosting symbiotic nitrogenfixing rhizobia results from two highly synchronized processes, namely, rhizobial infection and nodule organogenesis. In Lotus japonicus and Medicago truncatula, organogenesis is initiated by local reactivation of cell division in root cortical cells. This gives rise to nodule primordia that are targeted by infection threads initiated by invagination of root-hair plasma membranes. Both processes are triggered by rhizobial Nod factors

Current address for Y. Kawaharada: Department of Plant Bio Sciences, Faculty of Agriculture, Iwate University, 3-18-8 Ueda, Morioka, Iwate, Japan

Corresponding author: J. Stougaard; Telephone + 45 87155504; E-mail: stougaard@mbg.au.dk

*The $e$-Xtra logo stands for "electronic extra" and indicates that seven supplementary figures and four supplementary tables are published online.

(C) 2017 The American Phytopathological Society perceived by a Nod factor receptor complex that, in L. japonicus, consists of NFR1 and NFR5 as well as an interaction between SYMRK with NFR5 (Antolín-Llovera et al. 2014; Broghammer et al. 2012; Madsen et al. 2003; Radutoiu et al. 2003; Madsen et al. 2011). This initial recognition of Nod factor leads to expression of the EPR3 receptor, which subsequently perceives rhizobial exopolysaccharides and regulates rhizobial infection at the epidermis and the enclosure of bacteria by plant membranes during the subsequent progression of infection threads into nodule primordia (Kawaharada et al. 2015, 2017).

Transcriptome studies show that nodule development involves major changes in cellular, metabolic, and transcriptional activities (Colebatch et al. 2004; Høgslund et al. 2009; Trujillo et al. 2014). Compared with uninfected root tissue, several hundred genes are transcriptionally up- or down-regulated in different stages of the developmental process forming these new organs (Verdier et al. 2013). This resetting of the transcriptional landscape is triggered by signal perception and the downstream signal transduction. One of the first detectable physiological hallmarks of this process is calcium oscillations (spiking) in the perinuclear space of root hairs, leading to calcium-mediated conformational changes that activate the CCaMK protein (Miller et al. 2013; Miwa et al. 2006; Shimoda et al. 2012). Downstream of this signaling activation of transcription factors, including members of the RWP-RK, GRAS, AP2/ERF (APETALA2/Ethylene Responsive Factor), C2H2, ARID, NF-Y, bHLH, coiled-coil, and MYB classes, has been shown to play a role in the transcriptional regulation of genes involved in different stages of rootnodule development (Andriankaja et al. 2007; Cerri et al. 2012; Godiard et al. 2011; Middleton et al. 2007; Oldroyd 2013; Schauser et al. 1999, 2005; Sinharoy et al. 2013; Soyano and Hayashi 2014). The transcription factors were mainly identified by loss-of-function genetic approaches, and the mechanistic connection between the signaling and the spatio-temporal activities, interactions, and functional hierarchies of these transcription factors has only recently begun to emerge from molecular studies (Andriankaja et al. 2007; Middleton et al. 2007). CYCLOPS, a coiled-coil transcription factor that is directly phosphorylated by activated $\mathrm{CCaMK}$, induces Nin gene expression by phosphorylation-dependent binding at specific regulatory elements of the Nin gene promoter (Singh et al. 2014). The NIN transcriptional regulator then targets the promoters of $N f-y a l$ and $N f-y b l$ that encode subunits of the heteromeric CCAAT-box binding NF-Y nuclear factor complex (Soyano et al. 2013). These observations suggested a central position of CYCLOPS in the transcription-factor hierarchy. Supporting this notion, expression of a phosphomimic, CYLOPS-DD, was sufficient to induce spontaneous nodules similar to those induced in 
the snfl mutant, an autoactive CCaMK (Singh et al. 2014; Tirichine et al. 2006). Overexpression of Nin also induces spontaneous nodule-like structures (Soyano et al. 2013), suggesting that CYCLOPS-DD-induced spontaneous nodules form through NIN and activation of the NF-Y complex. Taking the loss-offunction phenotypes of nin and cyclops mutants into consideration, these observations suggest that CYCLOPS and NIN are key regulators of both infection-thread formation and organogenesis (Fournier et al. 2015; Schauser et al. 1999; Yano et al. 2008). Another transcription-factor pair, NSP1/NSP2, operates downstream of CCaMK. In M. truncatula, NSP1 binds promoter regions of Nin, Ern1, and ENOD11 and forms heteropolymers with NSP2 (Hirsch et al. 2009). It is still unclear whether this occurs in parallel with or downstream of CYCLOPS regulation. Detailed studies of transcription factors and promoter elements involved in ENOD11 expression illustrate the complexity of transcriptionfactor interactions. In $M$. truncatula, ERN1 (ERF Required for Nodulation1) and the NSP1/NSP2 complex both activate ENOD11 expression but different binding sites are involved (Cerri et al. 2012). In the early preinfection stage ERN1 activates Nod factor-elicited ENOD11 expression via the so-called NF box, while NSP1/NSP2 regulates ENOD11 expression during rhizobial infection. Additionally, ERN2, which overlaps the function of ERN1, can positively regulate ENOD11 expression and ern 1 ern 2 double mutants have a severe symbiotic phenotype compared with both ern1 and ern2 single mutants (Cerri et al. 2016). ERN3 appears to function as a repressor (Andriankaja et al. 2007). Further studies of ENOD11 activation suggest that activation of Ernl expression differs from NIN-NF-YA1 and the NSP1/NSP2 complex (Laloum et al. 2014); however, it is not clear how ERN2 acts together with ERN1. Although several other transcription factors have been implicated in nodule development, their functions or positions in the hierarchy are less well-defined. A bHLH factor is involved in nodule vasculature patterning (Godiard et al. 2011), and a $\mathrm{C} 2 \mathrm{H} 2$ factor controls VAMP721a expression and bacteroid development in late nodulation (Sinharoy et al. 2013). A MYB factor possibly interacts with NSP2 (Kang et al. 2014) or regulates nodule numbers (Libault et al. 2009), as observed with a basic leucine zipper and the miRNA172-controlled AP2s (Holt et al. 2015; Nova-Franco et al. 2015; Wang et al. 2014; Yan et al. 2013). Finally, at least two ERF-type transcription factors are positive regulators of nodulation in $L$. japonicus and $M$. truncatula (Asamizu et al. 2008; Vernié et al. 2008).

Many features of the molecular mechanisms governing the root-nodule developmental processes are similar in L. japonicus and $M$. truncatula. However, the formation of the new symbiotic organs follows distinct developmental paths. M. truncatula develops indeterminate nodules originating from cell division in the pericycle, endodermis, and inner cortex. These cell divisions lead to nodule primordia with a persistent meristem localized in the tip of the nodules, and these apical meristems produce new cells that are infected by continuously growing infection threads. L. japonicus nodules follow a determinate developmental path in which nodule primordia are initiated by cells in the outer cortex of $L$. japonicus roots and the nodules formed lack an apical meristem (Ferguson et al. 2010; Handberg and Stougaard 1992).

Here, we investigate the role of the L. japonicus ERF-type factor ERN1 in the nodule symbiosis signal pathway of determinate nodules connecting organogenesis with infectionthread formation in response to rhizobial signaling.

\section{RESULTS}

The ERN transcription-factor family.

The function of three ERN transcription-factor genes, Ern1, Ern2, and Ern3, has been investigated in M. truncatula, which forms indeterminate nodules (Andriankaja et al. 2007; Cerri et al. 2016; Middleton et al. 2007). In L. japonicus, which develops determinate nodules, only two Ern genes were found by analyzing the v3.0 genomic sequence (Lotus Base). The L. japonicus ERN1 (Lj1g3v3975310.1) protein is 76\% identical to M. truncatula ERN1, and L. japonicus ERN3 (Lj4g3v2604280.1) is $62 \%$ identical to M. truncatula ERN3. A L. japonicus homolog of the M. truncatula Ern2 was not found. To examine whether this is a genuine difference between legumes forming indeterminate and determinate nodules, the phylogeny of the ERN proteins was assembled. Cicer arietinum (chickpea) and Trifolium pratense (red clover), which form indeterminate nodules (Afonso-Grunz et al. 2014; Webb et al. 2013), have ERN1, ERN2, and ERN3. Glycine max (soybean), which forms determinate nodules, has duplicated genes encoding ERN1-1 and ERN1-2 and ERN3-1 and ERN3-2 but no ERN2, suggesting ERN2 is not essential for determinate nodulation. However, Phaseolus vulgaris (common bean), which forms determinate nodules (Martínez-Romero 2003), has three Ern genes, two of which encode proteins closer to $M$. truncatula ERN1 than ERN2. In the phylogenetic analysis, ERN1 and ERN2 are widespread among land plants. Members of genera Arabidopsis, Vitis, Ricinus, Oryza, and Sorghum have one and members of genera Brassica, Populus, and Solanum have three ERN1 homologs (Fig. 1A). In contrast, only plants belonging to the Leguminosae (Fabaceae) family are represented in the ERN3 group. This analysis suggests that a common AP2/ERF transcriptionfactor gene has undergone gene duplications in several land plants and that the Ern3 gene may have undergone neo-functionalization in legumes.

\section{Characterization of $\boldsymbol{L}$. japonicus ern1 mutant phenotypes.}

The L. japonicus Ernl gene, composed of one exon, is located on chromosome 1 and encodes a conceptual protein of 269 amino acids, corresponding to approximately $30.3 \mathrm{kDa}$. To characterize the symbiotic phenotype of ern 1 mutants, four monogenic recessive mutant alleles, ern 1-1, ern1-2, ern1-3, and ern 1-4, were obtained from the LORE1 mutant resource (Fukai et al. 2012; Małolepszy et al. 2016; Urbański et al. 2012) (Fig. 2A; Supplementary Table S1). Gifu wild-type plants start forming nodule primordia 7 days postinoculation (dpi) with Mesorhizobium loti R7A. At 10 dpi, we observed three to five pink nodules per plant (Fig. 2C). In comparison, none of the four ernl mutants had developed any nodule primordia at 14 dpi. However, ern1 mutants developed nodule primordia by 21 dpi. At 28 dpi, ern1 mutants had one to three pink nodules, approaching the developmental stage that was reached by Gifu at 14 dpi (Fig. 2B and C; Supplementary Fig. S1). To further investigate the role of ERN1 in nodule organogenesis, we assayed the effect of expressing the snfl autoactive CCaMK (T265D) in transgenic roots. Of 17 ern 1-2 transgenic root systems transformed with a pUbi:CCaMK (T265D) construct, none developed spontaneous nodules (Supplementary Fig. S2A through D). In contrast, 11 of 12 transgenic Gifu roots transformed with $p U b i: C C a M K$ (T265D) formed approximately 10 spontaneous nodules per root. To support this result, we tested the response of exogenous cytokinin in ernl mutants. No cytokinin-inducible nodule formation was observed in ern 1-1 and ern 1-2 mutants and Gifu plants treated with $10^{-8} \mathrm{M}$ benzylaminopurine developed nodule primordia as previously observed (Heckmann et al. 2011). These results suggest that ERN1 promotes nodule organogenesis and that this function is required for the spontaneous nodule development driven by the autoactive CCaMK and cytokinin signaling. The absence of spontaneous nodules on $23 n f r l-1$ plants transformed with pUbi:Ernl suggests that ERN1 promotion of organogenesis requires a combination of transcription factors. 
Ethylene influences the number of nodules in L. japonicus (Nukui et al. 2000) and several ERF-type transcriptional factors are controlled by ethylene signaling (Huang et al. 2016). The effect of an ethylene inhibitor (aminoethoxyvinylglycine [AVG]) and an ethylene precursor (1-aminocyclopropane-1-carboxylic acid [ACC]) on the nodulation of ernl mutants was investigated. A comparable effect was detected in inoculated ern 1 mutants and Gifu plants. AVG enhances nodulation whereas ACC reduces nodulation in both Gifu and ernl mutants (Fig. 2C). This indicates unchanged ethylene sensitivity in the ern1 mutants.

\section{ERN1 is required for development} of root-hair infection threads.

When examined $7 \mathrm{dpi}$, curled root hairs, infection pockets, and infection threads containing rhizobia were observed in Gifu plants, whereas root-hair curling and infection pockets were rarely found in ern 1 mutants (Fig. 2E and F). Approximately 50 infection threads per root, including short and long infection threads, were observed in Gifu plants at $7 \mathrm{dpi}$, whereas no infection threads were observed in ern 1-1 and ern 1-3 mutants. One short infection thread, which reached halfway down the length of the root hair, was observed in one of 13 ern 1-2 mutant plants (Fig. 2D). The root-hair responses of ernl mutants are closer to those of $n s p l$ and $n s p 2$ mutants (Heckmann et al. 2006) than to those of nin mutants, which show excessive root-hair responses in L. japonicus (Schauser et al. 1999) (Fig. 2F). The L. japonicus ernl infection-thread phenotype is also more comparable to that of the $M$. truncatula ern1 ern2 double mutant than the M. truncatula ern1 single mutant (Cerri et al. 2016).

\section{Irregular peg-type infection of ern1 mutants.}

Microscopy of the pink nodules that developed in ern $1 \mathrm{mu}-$ tants at 28 dpi revealed that bacteria were endocytosed into the nodule cells and had differentiated into bacteroids (Fig. 3C, F, and I). Closer inspection of 10 different nodule sections revealed an absence of normal transcellular cortical infection threads in ernl mutant nodules. Only irregular peg-type infections were found in these nodules (Madsen et al. 2010) and, most likely, they release rhizobia into the infected cells of ern 1 mutants (Fig. 3E and F). Rhizobia were also found between the plant cells in ern1 nodules (Fig. 3H and I). Supporting these observations, crack entry sites were found adjacent to curled root hairs (Fig. 3G). These results suggest that ERN1 is required for and involved in infection-thread formation in the root epidermis and in cortical root nodules.

\section{Complementation of ern1 mutant \\ with L. japonicus Ern1 and Arabidopsis Rap2.11.}

The phylogenetic tree suggested that Arabiodopsis RAP2.11 is a homolog of L. japonicus ERN1 and, previously, RAP2.11 was suggested as the ortholog of M. truncatula ERN1 (Kim et al. 2012). The AP2/ERF domain, which directly binds to promoter elements, is also well-conserved between Arabidopsis RAP2.11, L. japonicus ERN1, and M. truncatula ERN1 (Fig. 1B). In order to compare the function of Arabidopsis Rap2.11 and L. japonicus Ern1, comparable gene constructs were transformed into Gifu and ernl-2 mutants. The pUbi:Ernl construct complemented ern 1-2 and infection threads were formed and effective nodules appeared 2 and 3 weeks postinoculation (wpi) with M. loti MAFF3030399 DsRed (Supplementary Fig. S3A

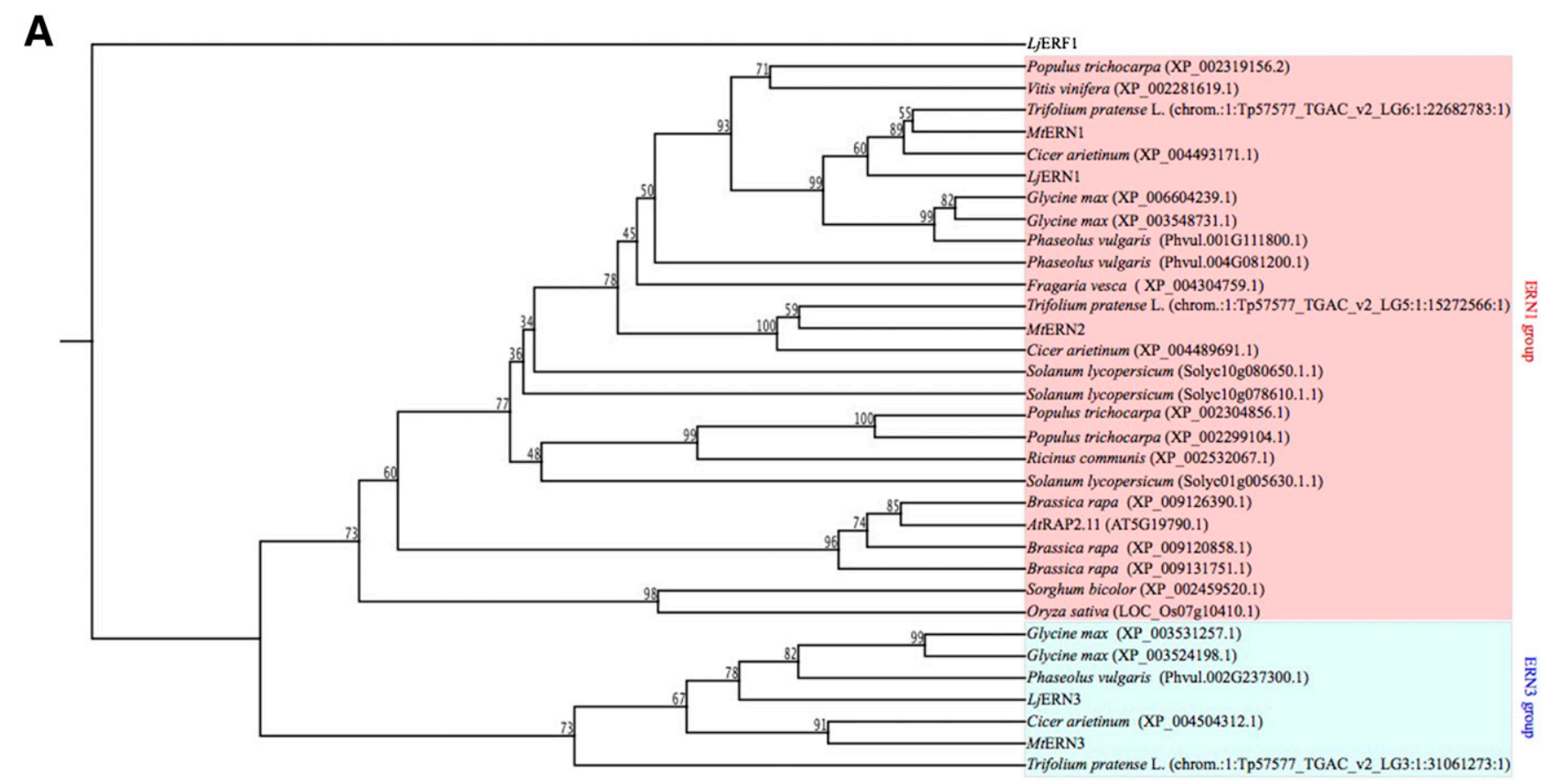

0,250

B

AP2/ERF domain

ATRAP2.11 11 ................-MEHQTTPKQKTKEKSKGNKTKFVGVRQRPSGKWVAEIKDTTQKIRMWLGTFETAEEAARAYDEAACLLRGSNTRTNFANHFPNNSQLSLKIRNLLHQKQSMKQ 103 LJERN1 1 MEIQFQQPNLQQHQK---AGTKGGKFKGRNRNS -NTNKFVGVRQRPSGRWVAEIKDTTQKIRMWLGTFETAEEAARAYDEAACLLRGSNTRTNFITHVSLDSPLASRIRNLLNNKKGNKK 116 MTERN1 1 MEIQFQQPNMQNQKAGISVTNKGGKFKGRNRNSNNTNKFVGVRQRPSGRWVAEIKDTTQKIRMWLGTFETAEEAARAYDEAACLLRGSNTRTNFITHVSLDSPLASRIRNLLNNRKGDKK 12

Fig. 1. Phylogeny of ERN (ethylene-responsive factor [ERF] required for nodulation) transcription factors in plants. A, Phylogenetic tree of ERN proteins from monocot and dicot plants. Lotus japonicus ERF1 (Asamizu et al. 2008) is included as an outgroup. The ERN1 group including Medicago truncatula ERN2 (top) and the ERN3 group (bottom). B, The alignment of AP2/ERF domains from Arabidopsis thaliana RAP2.11, Lotus japonicus ERN1, and M. truncatula ERN1. 
and B). Interestingly, Gifu and ern 1-2 transformed with pUbi:Ernl express Ern1 at levels 30-fold higher than that in roots transformed with the empty vector, and a reduction of nodule numbers in Gifu, reflecting a partial complementation of ern1-2, was observed. The pUbi:Rap2.11 enhanced nodulation at the 2-wpi timepoint but any later effect was insignificant. These observations support the ern 1 mutant characterization.

\section{Ern1 is not required}

for arbuscular mycorrhiza (AM) symbiosis.

Previous studies have shown that several genes serve a function in symbiosis with AM fungi and in root-nodule symbiosis (Kouchi et al. 2010). The AM symbiotic phenotype of ern 1 mutants was, therefore, tested with Rhizophagus intraradices. No difference was observed between Gifu and ern 1-2 mutants, although the ccamk-13 mutants used as a negative control showed the expected absence of AM symbiosis. Corroborating this result, AM symbiosis did not induce Ernl expression, measured using $p E r n 1$ :GUS activity in transgenic roots (Supplementary Fig. S4). These data suggest that L. japonicus
ERN1, like $M$. truncatula ERN1 and ERN2 (Cerri et al. 2016), has a specific function in root-nodule symbiosis and is unlikely to play a major role in AM symbiosis.

\section{Expression of Ern1.}

The symbiotic phenotype of ernl mutants showed the involvement of ERN1 in both infection-thread and nodule development. To investigate this at the cellular level, the spatiotemporal expression pattern was determined using reverse transcriptionquantitative polymerase chain reaction (RT-qPCR) and a pErn1:GUS reporter gene. Increased transcript levels of Ern1 were detected in Gifu plants at 8 and $24 \mathrm{~h}$ postinoculation (hpi) with M. loti R7A (Fig. 4M), whereas Ernl upregulation was undetectable in Gifu plants inoculated with a M. loti nodC mutant unable to synthesize Nod factor (Fig. 4N). Similarly, Ernl induction was not detected in M. loti R7A-inoculated $n f r 1-1$ and $n f r 5-2$ mutants lacking the Nod factor receptor (Fig. $4 N$ ). In contrast, treatment of Gifu with purified Nod factor at $10^{-8} \mathrm{M}$ induces rapid Ernl expression (Fig. 5). The cellular localization of expression was determined using a reporter
A

810 bp (269 amino acids)

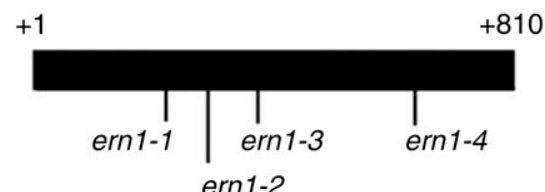

B

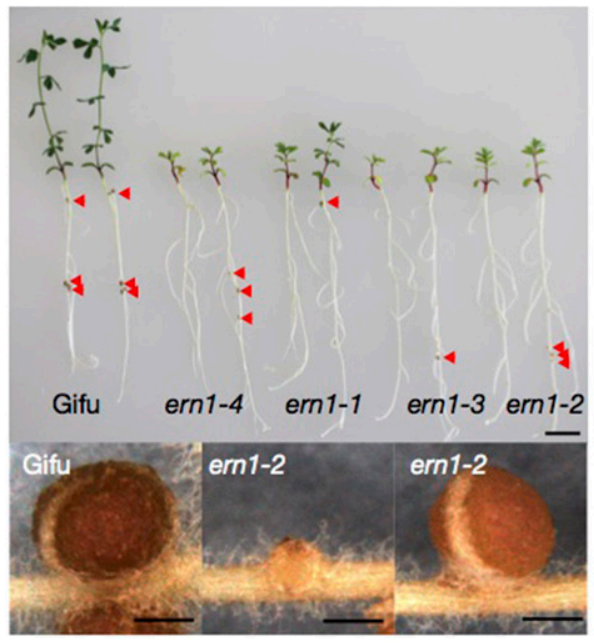

C

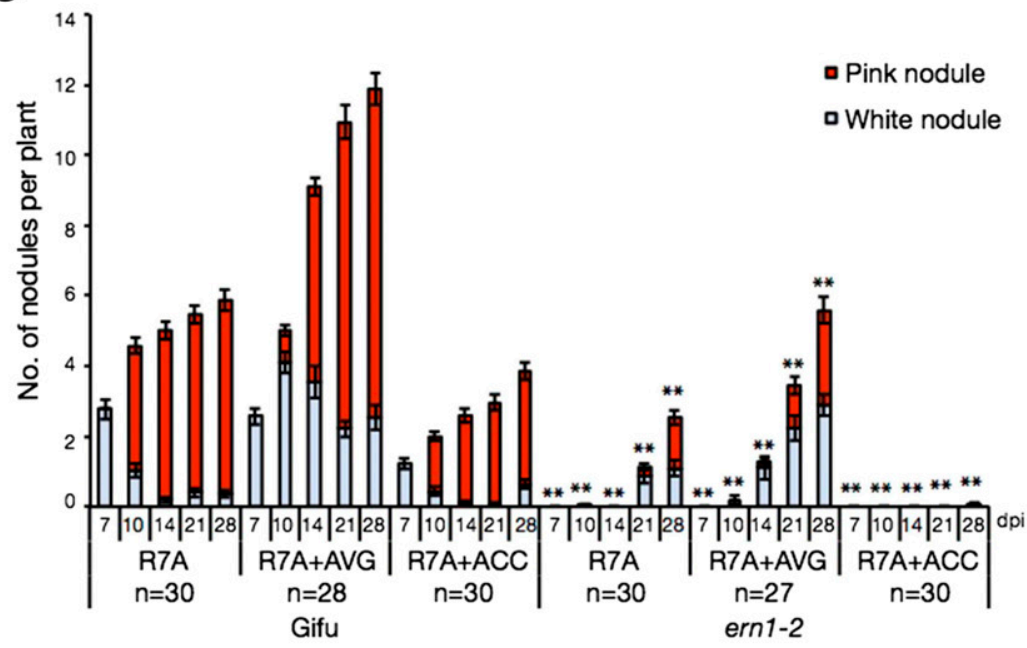

E

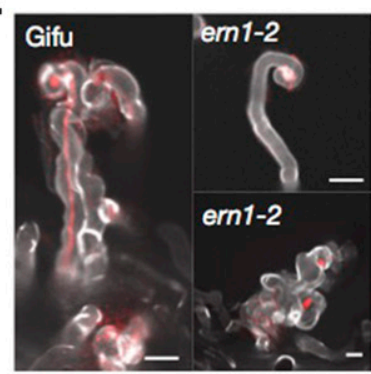

$F$

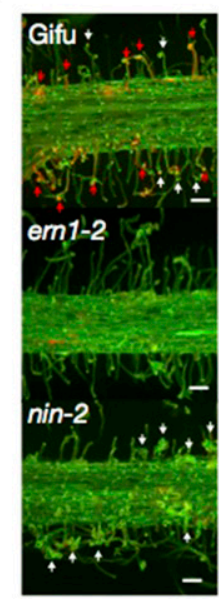

Fig. 2. Symbiotic phenotypes of ern1 mutants inoculated with Mesorhizobium loti. A, Schematic gene model of Ern1 and the position of LORE1 retrotransposon insertions in ern 1 mutants. B, Symbiotic phenotype of ern 1 mutants 28 days postinoculation (dpi) with $M$. loti R7A. From left, two plants of Gifu, ern 1-4, ern 1-1, ern1-3, and ern 1-2. Panels at the bottom show images of nodule and nodule primordia in Gifu and ern1-2. Red triangles indicate pink nodules. C, Nodulation kinetics of Gifu and ern 1-2 mutants inoculated with $M$. loti R7A with and without $3.5 \mu \mathrm{M}$ aminoethoxyvinylglycine (AVG) or $1.0 \mu \mathrm{M}$ 1-aminocyclopropane-1-carboxylic acid (ACC). D, Number of infection threads formed 7 dpi with M. loti R7A DsRed in Gifu, ern1-1, ern1-2, and ern1-3. E, Infection threads formed in Gifu and defective infection threads and excessive root-hair curling in the ern1-2 mutant. F, Infection threads and root-hair deformation 7 dpi with $M$. loti R7A DsRed in Gifu, ern 1-2, and nin-2 mutants. Red arrows indicate infection thread, and white arrows show root-hair curling in Gifu and excessive root-hair curling in the nin mutant. Two asterisks (**) $(P<0.01)$ indicate significant differences comparable to total number of nodules or infection threads in Gifu plant. Bars are $1 \mathrm{~cm}$ and $0.5 \mathrm{~mm}$ in $\mathrm{B}, 20 \mu \mathrm{m}$ in $\mathrm{E}$, and $100 \mu \mathrm{m}$ in $\mathrm{F}$. 
gene, pErn1:GUS, with a 2.2-kb Ernl promoter fused to a $\beta$-glucuronidase (GUS) reporter. Expression in uninoculated transgenic roots was barely detectable, whereas a high level of GUS activity was found in epidermal cells and root hairs of the susceptible zone at $3 \mathrm{dpi}$ (Fig. 4B, F, and J). Between 5 and 10 dpi, GUS activity was detected in cortical cells initiating nodule primordia formation and in young nodules (Fig. 4C, D, G, H, K, and L). At this stage of nodule development, pErn1:GUS expression was decreasing in epidermal cells (Fig. 4D).

\section{Genetic position of Ern1.}

The arrested infection-thread formation phenotypes in ernl mutants are reminiscent of phenotypes observed in cyclops, $n s p 1, n s p 2$, and nin mutants (Heckmann et al. 2006; Schauser et al. 1999; Yano et al. 2008). In order to position Ernl in the genetic hierarchy of these transcription factors, we tested expression in the corresponding loss-of-function mutants $12 \mathrm{~h}$ after treatment with $10^{-8} \mathrm{M}$ Nod factor. Induction of Ernl was Nfrl dependent, and normal Ernl transcript levels were found in $n i n-2$ and $n f$-yal mutants, whereas an intermediate induction was detected in cyclops-2, nsp 1-1 and nsp2-3 mutants (Fig. 5). Corroborating this result, pErnl:GUS expression following $M$. loti inoculation was indistinguishable in epidermal cells of Gifu, nin-2, and nin-7 mutants. In contrast, pErn1:GUS expression was undetectable in $n f r l-1, n s p 2-3$, and cyclops-2 mutants, although expression was found in epidermal cells of nsp 1-1 mutant at 5 dpi with M. loti (Supplementary Fig. S5). At later timepoints, when cyclops-2 and nsp1-1 mutants had formed nodule primordia, pErn1:GUS expression was detected in the cortical nodule primordia. This result suggests that Cyclops is necessary for Ernl induction in the epidermis but not in the cortex. pErn1:GUS expression was also found in snf2-induced spontaneous nodules.

\section{Downstream components.}

Given the phenotype of ern l mutants and the role of AP2/ERF proteins as transcription factors, we examined the L. japonicus transcriptome for genes acting downstream of ERN1. Candidates were found among genes from a transcriptome study (Høgslund et al. 2009), and genes induced 1 to 7 dpi with $M$. loti but not by the $M$. loti nodC were selected (Supplementary Fig. S6; Supplementary Table S2). The following set was investigated further: Chi4, encoding a legume-specific chalcone isomerase involved in flavonoid synthesis (Shimada et al. 2003); Publa and $P u b 1 b$, homologs of $M$. truncatula Publ encoding a U box-dependent E3 ubiquitin ligase (Mbengue et al. 2010); and Puch/ERF086, a homolog of Arabidopsis Puchi encoding an AP2 transcription factor (Hirota et al. 2007; Kazusa DNA Research Institute et al. 2000). RT-qPCR showed that Chi4, Publa, and $P u b l b$ were induced 4 to 8 hpi with $M$. loti R7A, and Puchi was induced 12 to $24 \mathrm{hpi}$ (Supplementary Fig. S7A). Induction of all these genes depends on Nfrl, Nfr5, and Nod factor. Distinct expression patterns were detected among this gene set. Chit, $P u b l a$, and Publb were expressed early, whereas Puchi was expressed at later timepoints. The gene dependencies of these two patterns were, therefore, investigated in L. japonicus loss-of-

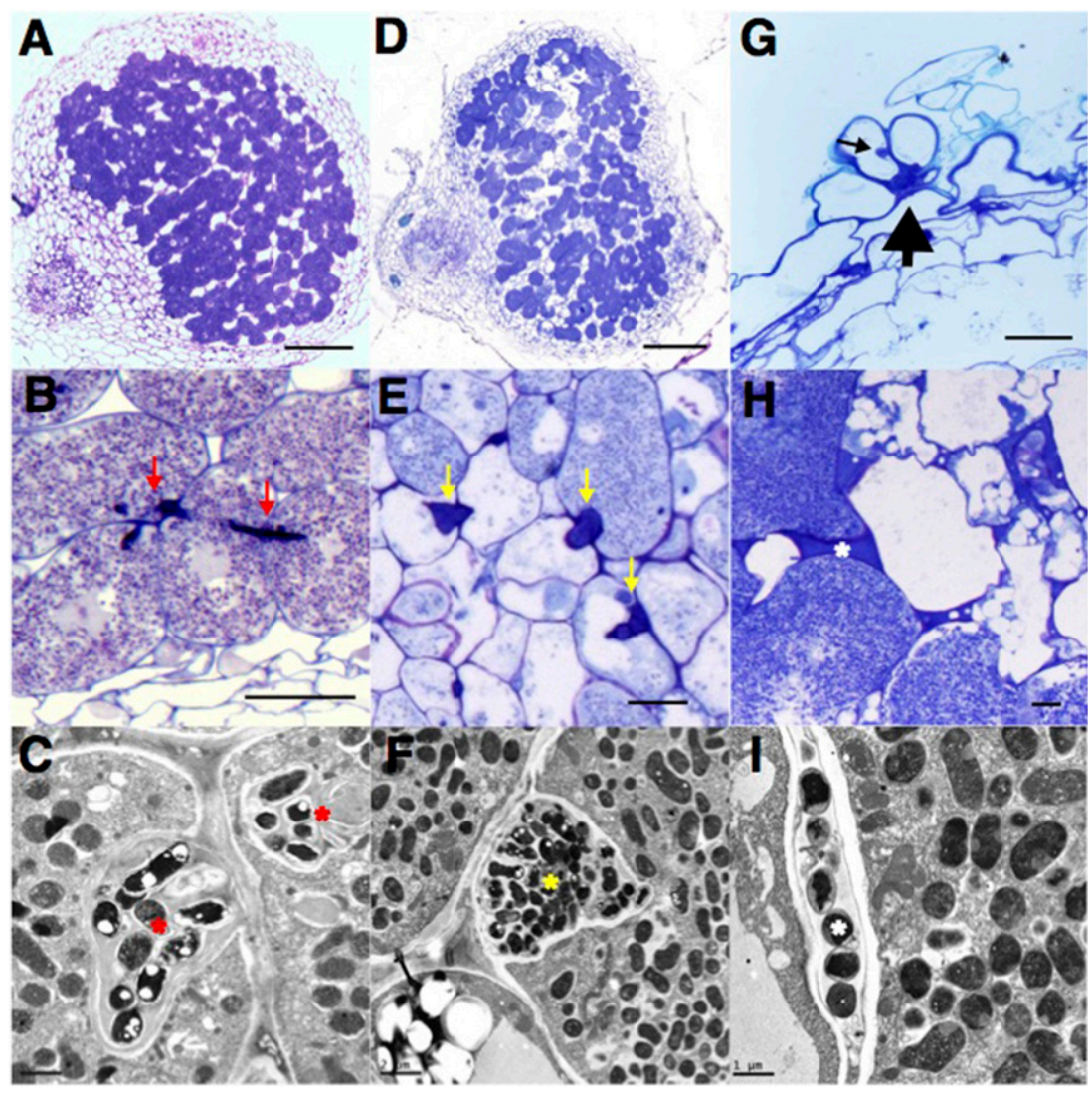

Fig. 3. Transcellular infection threads in the nodule. A to C, Gifu nodules at 14 days postinoculation (dpi) with Mesorhizobium loti R7A. D to I, ern1-2 (D, G, E, H) and ern 1-4 (F, I) mutant nodules at 28 dpi with M. loti R7A. A and D, show whole nodule sections of Gifu and ern1 mutant stained by toluidine blue. Dark blue indicates infected cells containing bacteroids. B and $\mathbf{C}$, Transcellular infection in Gifu wild-type nodules. $\mathbf{E}$ and $\mathbf{F}$, Irregular peg-type infection in ern 1 nodules. G, Crack entry site adjacent to curled root hairs in ern1 mutant. $\mathbf{H}$ and $\mathbf{I}$, Rhizobia between nodule cells. Red arrows and stars indicate transcellular infection threads. Yellow arrows and stars show a peg-type of infection. White stars show colonization of rhizobia between nodule cells. A small black arrow shows bacteria colonization in the root-hair curling and a large black arrow shows the crack entry site. Bars show $200 \mu \mathrm{m} \mathrm{in} \mathrm{A} \mathrm{and} \mathrm{D,} 10 \mu \mathrm{m}$ in B, E, G, and H, $1 \mu \mathrm{m}$ in $\mathrm{C}$ and $\mathrm{I}$, and $2 \mu \mathrm{m}$ in $\mathrm{F}$. 
function mutants at $12 \mathrm{~h}$ posttreatment with $10^{-8} \mathrm{M}$ Nod factor (Fig. 5). Induction of Chi4, Publa, and Publb depends on Nfrl, Nsp2 and Ern1, but was independent of Nin and Nf-yal. Interestingly, Chi4 is independent of Cyclops and Publb is independent of Nspl but Publa depends on both Cyclops and Nspl. These RT-qPCR results suggest that Chi4, Publa, and $P u b 1 b$ expression is downstream of ERN1. In contrast, Puchi expression clearly depends on Nspl, Ernl, and Nin.

\section{DISCUSSION}

Several transcription factors, including CYCLOPS, NSP1, NSP2, and NIN, have been characterized in both $M$. truncatula and $L$. japonicus. These transcription factors are essential for root-nodule symbiosis and CYCLOPS, NSP1, and NSP2 also play a role in AM symbiosis (Heckmann et al. 2006; Takeda et al. 2013; Yano et al. 2008). Here, we present the L. japonicus ERN transcription factors and characterize ERN1, using four LORE1 retrotransposon mutants. All ern l alleles showed the same delayed nodule formation phenotype after inoculation with $M$. loti, and further detailed analyses of ern 1 mutants revealed that root-hair infection threads and normal transcellular infection threads were absent. The ern1-2 allele was complemented for both root-hair infection threads and nodule formation by the Ernl gene. This phenotype distinguishes ernl mutants from other $L$. japonicus mutants with a defect in infection-thread development, such as nap, pir, and cerberus (Yano et al. 2009; Yokota et al. 2009). These mutants develop excessive numbers of small, uninfected nodule primordia, whereas ernl mutants form a reduced number of nodules infected by crack entry after a lag period. This phenotype suggests that ERN1 is required for infection-thread formation. Previous results showed that ERN1 is required for expression of the EPR3 exopolysaccharide receptor that controls infection- thread formation and that lack of Epr3 gene expression in the ernl mutants is likely to contribute to the infection-thread phenotype (Kawaharada et al. 2017). In the nodule developmental process, ERN1 has a function in promoting organogenesis, with ernl mutants developing primordia with a delay. The suggested function of ERN1 in nodule organogenesis is also supported by the lack of spontaneous nodules in ern 1 roots transformed with the snfl autoactive CCaMK (T265D) and the absence of cytokinin-induced primordia. These data suggest that ERN1 promotes organogenesis rather than being strictly required in the process.

As shown in Figure 4B and D, M. loti inoculation rapidly induces Ern1 expression in epidermal cells. Later on, this epidermal expression fades out when nodule primordia develop from cell divisions in the cortex. It may be important that Ern1 expression follows this developmental pattern and is decreased with proper timing. Supporting this suggestion, constitutive overexpression of Ernl from the pUbi:Ern1 construct results in a reduced nodule number in Gifu control plants and, in ern 1-2, the normal number of nodules was not obtained. These data suggest that Ern1 may function both positively and negatively, similar to NIN (Cerri et al. 2016; Vernié et al. 2015; Yoro et al. 2014).

In $M$. truncatula, both ERN1 and ERN2 contribute to rhizobial infection and nodule organogenesis (Cerri et al. 2016) and ERN1 is up-regulated in root-nodule symbiosis and ERN2 is up-regulated in AM symbiosis (Hogekamp and Kuster 2013; Hogekamp et al. 2011). From complement analysis, it has been suggested that, during evolution, $M$. truncatula ERN1 was duplicated from ERN2 to serve for rhizobial interaction (Vanneste et al. 2014; Young et al. 2011). We did not find an Ern2 homolog in L. japonicus, although involvement of an unidentified AP2/ERF transcriptional factor that overlaps the function of $M$. truncatula ERN2 cannot be excluded (Handa et al. 2015). Another difference is that L. japonicus Ernl is only
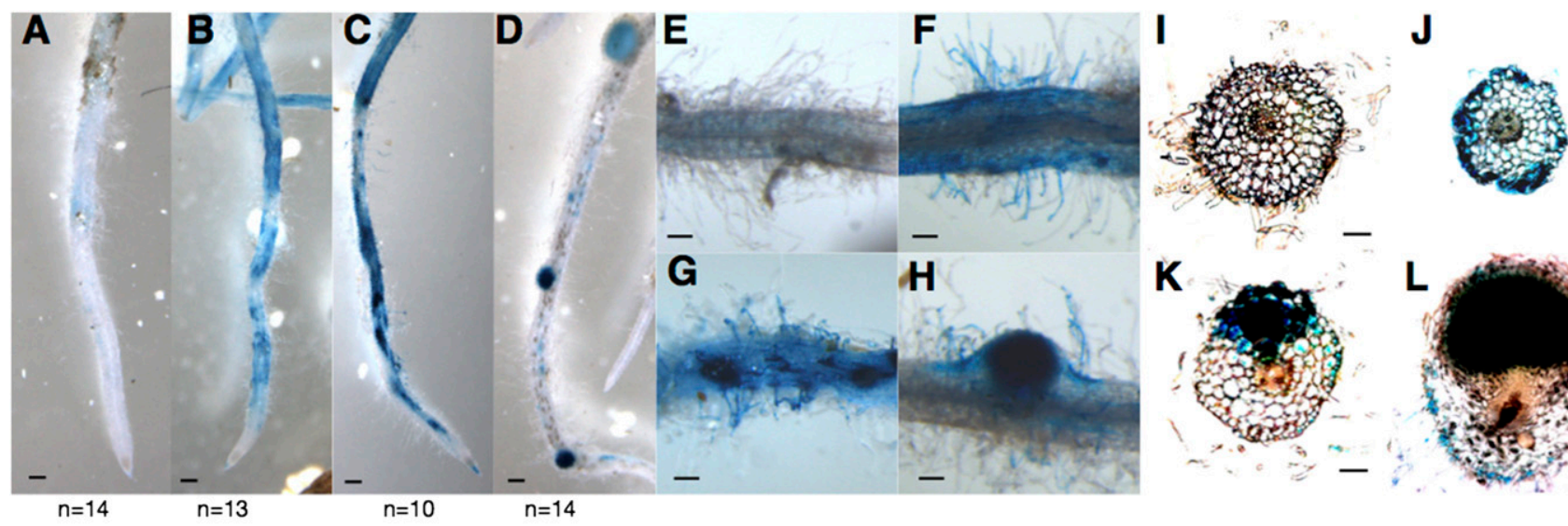

M

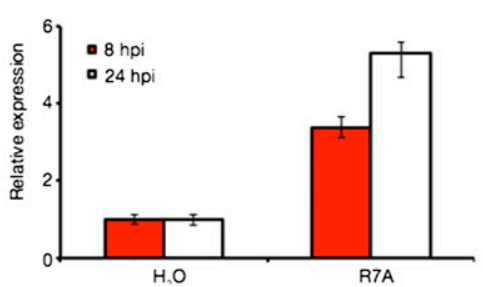

N

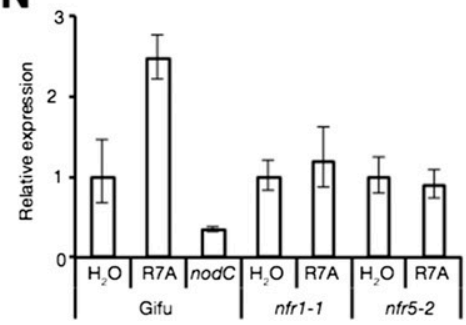

Fig. 4. Ern1 expression during symbiosis. A to L, Gifu plants transformed with pErn1:GUS at 0 to 10 days postinoculation (dpi) with Mesorhizobium loti R7A. $\mathbf{A}, \mathbf{E}$, and I, Uninoculated transgenic roots, and roots at $\mathbf{B}, \mathbf{F}$, and $\mathbf{J}, 3 \mathrm{dpi}, \mathbf{C}, \mathbf{G}$, and $\mathbf{K}, 5 \mathrm{dpi}$, and $\mathbf{D}, \mathbf{H}$, and $\mathbf{L}, 10 \mathrm{dpi}$. M, The relative expression of Ern 18 or 24 hpi with $M$. loti R7A on Gifu (M), and N, 24 hpi with $M$. loti R7A or nodC mutant on Gifu, nfrl-1 or $n f r 5-2$. These graphs show Ern1 expression levels relative to $\mathrm{H}_{2} \mathrm{O}$ treatment in each genotype. The relative expression ratio for the three biological and technical replicates and error bars represent the $95 \%$ confidence interval. Scale bars are $0.5 \mathrm{~mm}$ in $\mathrm{A}$ to $\mathrm{H}$ and $50 \mu \mathrm{m}$ in $\mathrm{I}$ to $\mathrm{L}$. 
induced by rhizobia and not by AM symbiosis (Handa et al. 2015). In addition, the delayed nodule primordia of $L$. japonicus ernl mutants are infected by rhizobia via an alternative crack entry mechanism. Previous research found that $M$. truncatula ERN1 and ERN2 bind directly to the Enod11 promoter region at the NF binding box (Andriankaja et al. 2007; Cerri et al. 2012). Recent results have shown that the pEpr3:GUS expression in the epidermal cells depends on Ern1 and an ERN1 binding site (GCCGTC) in the Epr3 promoter region, similar to the original AP2/ERF (GCCGCC) and RAP2.11 (GCCGGC) binding sites, was delimited (Kawaharada et al. 2017; Kim et al. 2012). These AP2 binding sites are also present in the promoter regions of the downstream Publa, and Publb genes (Supplementary Table S3). However, no NF binding box or AP2 binding sites
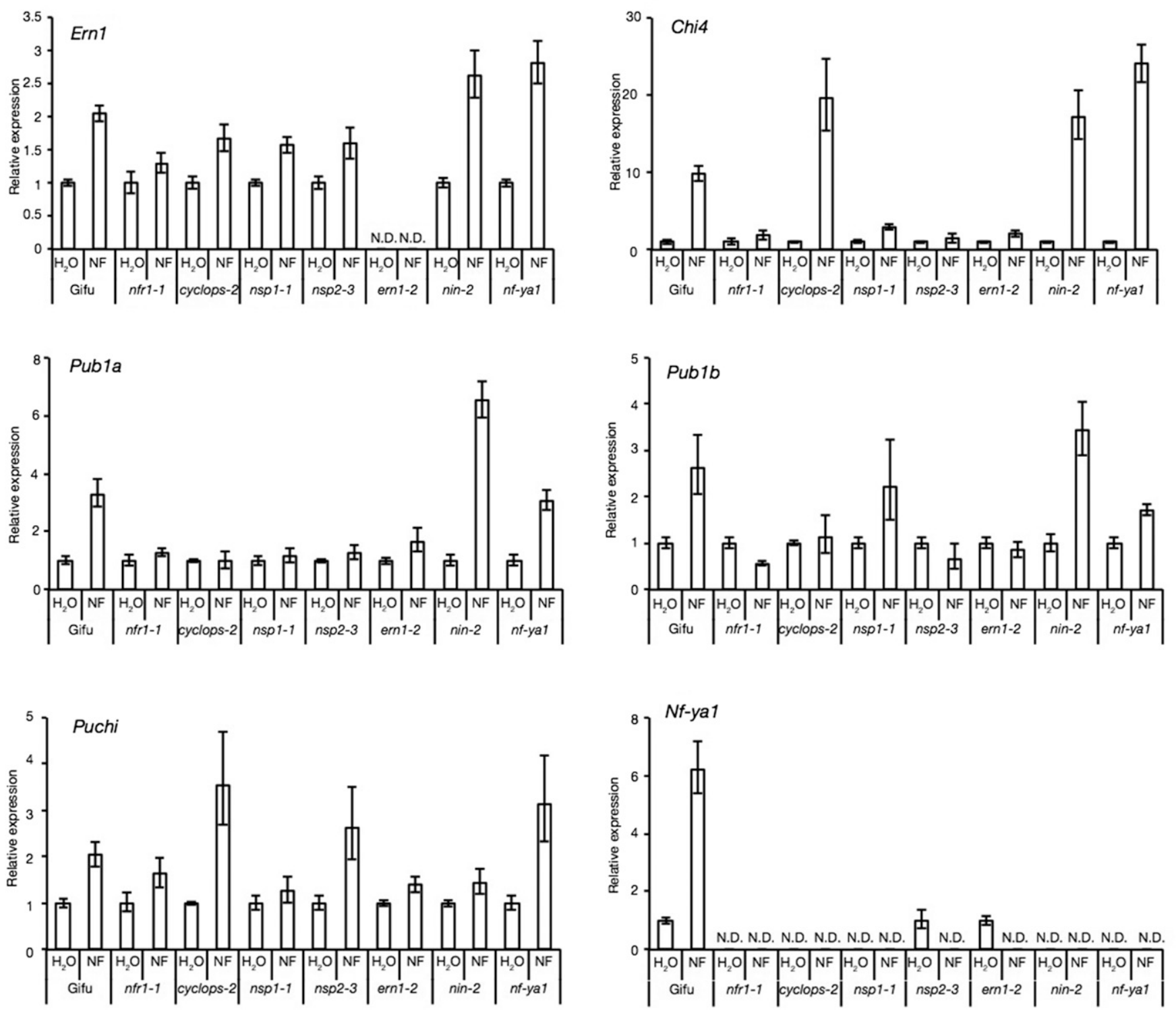

Fig. 5. Gene expression in symbiotic mutants. The relative expression of Ern1, Nf-yal, Chi4, Publa, and Publb $12 \mathrm{~h}$ after treatment with $10^{-8} \mathrm{M}$ Nod factor in Gifu, $n f r 1-1$, nsp1-1, nsp2-3, ern1-2, nin-2, or $n f-y a 1$ mutants. These graphs show gene expression levels relative to $\mathrm{H}_{2} \mathrm{O}$ treatment. The relative expression ratio for the three biological and technical replicates and error bars represent the $95 \%$ confidence interval. N. D. is not detected gene expression.

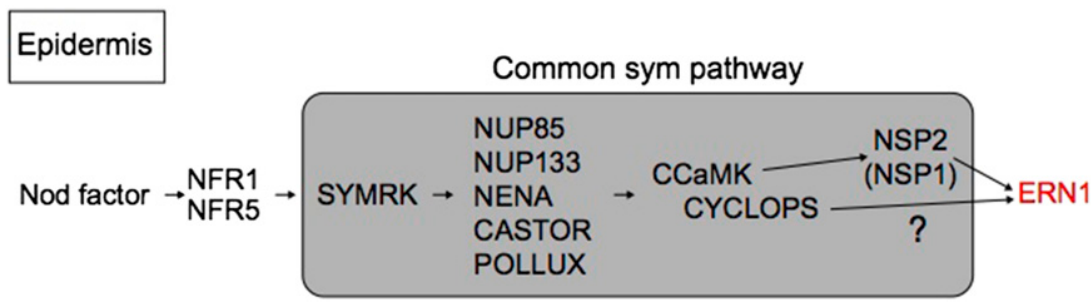

Fig. 6. Model of the genetic pathway required for Ernl induction. In the epidermis, Nod factor induces the symbiotic signal pathway through direct interaction with NFR1 and NFR5 receptors. Signal transduction through the common symbiotic pathway activates CCaMK-CYCLOPS and NSP2 (NSP1). CCaMK-NSP2 (NSP1) and CCaMK-CYCLOPS subsequently induce Ern1. 
were identified in the $2.1-\mathrm{kb}$ Chi4 putative promoter regions. The different behavior of ERN transcription factors between $M$. truncatula and L. japonicus is also reflected in the dependencies for gene expression. Laloum et al. (2014) suggested M. truncatula has two induction pathways regulating Ernl. One is via the NF-YA1 transcription factor that is downstream of NIN and directly controls Ernl expression. The other pathway involves NSP1/NSP2 transcription factors that also induce Ern1 expression (Cerri et al. 2012; Laloum et al. 2014). Supporting this pathway, M. truncatula NSP1 was observed to bind directly to the Ernl promoter (Hirsch et al. 2009). In L. japonicus, our data suggest similar Ernl expression in nin and $n f$-yal mutants and Gifu wild type after Nod factor treatment (Fig. 5). Likewise, pErn1:GUS induction in the epidermis is independent of Nin. These expression data and phenotypic observations suggest that ERN1 may be positioned differently in the transcription-factor hierarchy of epidermal cells of $M$. truncatula and L. japonicus.

Based on our RT-qPCR and promoter GUS data, we propose a model of the transcription-factor hierarchy acting downstream of CCaMK in the epidermis (Fig. 6). Calcium spiking activates CCaMK and, subsequently, NSP2 and maybe also NSP1 are activated in one branch and CYCLOPS in another (Yano et al. 2008). Both of these pathways are needed for ERN1 and NIN to support $N f$-yal induction (Fig. 5). Supporting this dual regulation of Ernl, putative CYCLOPS-binding sites (underlined in the following sequences: TGGCAAGCATGGCT and TGGCAGTCGTTCA TGCCT) were found in the Ernl promoter region. Future experiments are needed to investigate the interactions of ERN1 and NIN in the epidermis and cortex as well as the regulation of the downstream components identified in this study.

\section{MATERIALS AND METHODS}

Plant material and growth conditions.

Lotus japonicus ecotype Gifu (Handberg and Stougaard 1992) was used as the wild-type plant. The ernl and $n f-y a l$ mutants were LORE 1 retrotransposon insertions (Fukai et al. 2012; Urbański et al. 2012) (Fig. 1). nfrl-1, nfr5-2, nsp1-1, nsp 2-3, cyclops-2, nin-2, and nin-7 mutants were previously described (Heckmann et al. 2006; Madsen et al. 2003, 2005; Radutoiu et al. 2003; Schauser et al. 1999; Yano et al. 2008). Seed sterilization and plant-growth setups were carried out as previously described (Kawaharada et al. 2015). Plants were grown at $21^{\circ} \mathrm{C}$ with day and night cycles of 16 and $8 \mathrm{~h}$, respectively. Plants were inoculated with bacterial suspensions at an optical density at $600 \mathrm{~nm}=0.02$, if necessary.

\section{Bacterial strains and growth conditions.}

Wild-type strains Mesorhizobium loti R7A (Kelly et al. 2014; Sullivan et al. 2002) and MAFF303099 (Kaneko et al. 2000) along with the nodC mutant were grown in tryptone yeast and yeast mannitol broth medium at $28^{\circ} \mathrm{C}$. The construction of DsRed-tagged strains used in microscopy experiments has previously been described (Kawaharada et al. 2015; Kelly et al. 2013; Maekawa et al. 2009). Agrobacterium rhizogenes AR1193 strains (Hansen et al. 1989; Stougaard et al. 1987) were used for all hairy root transformation experiments, according to previously described methods (Petit et al. 1987). The following concentrations of antibiotics were used for M. loti and Agrobacterium strains: ampicillin, $100 \mu \mathrm{g} \mathrm{ml}^{-1}$; tetracycline, 2 to $10 \mu \mathrm{g} \mathrm{ml} \mathrm{m}^{-1}$; gentamicin, $50 \mu \mathrm{g} \mathrm{m} \mathrm{m}^{-1}$; rifampicin, $100 \mu \mathrm{g} \mathrm{ml}^{-1}$; and spectinomycin, $100 \mu \mathrm{g} \mathrm{ml}^{-1}$.

\section{AM symbiosis.}

Seedlings were gown in the dark for 5 days and, then, after germination, in day and night cycles of 16 and $8 \mathrm{~h}$, respectively, for 8 days. They were sandwiched within nitrocellulose membranes (GSWP, $0.22 \mu \mathrm{m}$; Merck Millipore), together with 50 spores of Rhizophagus irregularis (Symbion Ltd.) in Magenta boxes containing sand (Muregrus 0 to $4 \mathrm{~mm}$; Solid Products, Inc.) (Giovannetti et al. 1993). These were supplied with $50 \mathrm{ml}$ of Long Ashton solution $\left(0.75 \mathrm{mM} \mathrm{MgSO}_{4}, 1 \mathrm{mM}\right.$ $\mathrm{NaNO}_{3}, 1 \mathrm{mM} \mathrm{K} \mathrm{SO}_{4}, 2 \mathrm{mM} \mathrm{CaCl}, 3.2 \mu \mathrm{M} \mathrm{Na}_{2} \mathrm{HPO}_{4}, 25 \mu \mathrm{M}$ FeNa-EDTA, $5 \mu \mathrm{M} \mathrm{MnSO}_{4}, 0.25 \mu \mathrm{M} \mathrm{CuSO}_{4}, 0.5 \mu \mathrm{M} \mathrm{ZnSO}_{4}$, $25 \mu \mathrm{M} \mathrm{H}_{3} \mathrm{BO}_{3}, 0.1 \mu \mathrm{M} \mathrm{Na}_{2} \mathrm{MoO}_{4}$ ). Plants were grown at $21^{\circ} \mathrm{C}$ with day and night cycles of 16 and $8 \mathrm{~h}$, respectively, for 3 weeks, after which roots were scored for AM colonization by ink staining as previously described (Małolepszy et al. 2015).

\section{Light and transmission electron microscopy (TEM).}

Nodule sections for light and TEM were prepared using previously described methods (Madsen et al. 2010). Semithin sections $(1 \mu \mathrm{m})$ of nodule for light microscopy and ultra-thin $(70 \mathrm{~nm})$ sections for TEM were cut using a Leica UCT ultramicrotome. Light microscopy was performed using a Zeiss Axioskop and TEM using a JEOL JEM 1400.

\section{GUS staining.}

L. japonicus roots were stained with $0.5 \mathrm{mg}$ 5-bromo-4chloro-3-indolyl- $\beta$-D-glucuronic acid per milliliter, $100 \mathrm{mM}$ potassium phosphate buffer ( $\mathrm{pH} 7.0), 1 \mathrm{mM}$ potassium ferricyanide, $1 \mathrm{mM}$ potassium ferrocyanide, and $0.1 \%$ Triton $\mathrm{X}-100$. L. japonicus roots were incubated at $21^{\circ} \mathrm{C}$ overnight.

\section{Promoter and expression constructs.}

A putative Ern1 promoter region of 2,178 bp and a fulllength Ern1 in L. japonicus and a Rap2.11 in Arabidopsis genes were amplified from L. japonicus Gifu or A. thaliana Col-0 genomic DNA by PCR, using primers containing $a t t B$ sites and recombined into pDONR207 (Invitrogen), using the Gateway $\mathrm{BP}$ reaction (Invitrogen) to create the entry clones $p D O N R 207$ : pErn1, pDONR207:Ern1, and pDONR207:Rap2.11. Entry clones were recombined using Gateway LR reactions (Invitrogen) with destination vector pIV10:GW:GUS and pCAMBIA1300: Ljubiquitin promoter: $G W$ (Maekawa et al. 2008) to create the pIV10:pErn1:GUS, pCAMBIA1300:Ljubiquitin promoter:Ern1, and pCAMBIA1300:Ljubiquitin promoter:Rap2.11 constructs.

\section{RT-qPCR gene expression analysis.}

For gene expression analysis, 10 plants were grown on $1 / 4$ Broughton and Dilworth plates and were either inoculated with M. loti R7A or water, or were treated with $10^{-8} \mathrm{M}$ Nod factor or water within $24 \mathrm{~h}$, or three transgenic hairy root plants were inoculated at 3 wpi with $M$. loti MAFF303099 before the roots were harvested. Three biological replicates were performed for each combination of mutant and timepoint. mRNA extraction, quality control checks, and gene expression analysis using a Lightcycler 480 instrument (Roche) was performed as previously described (Kawaharada et al. 2015). Primer sets and conditions are shown in Supplementary Table S4.

\section{ACKNOWLEDGMENTS}

We thank J. Sullivan (University of Otago, New Zealand) and N. N. Maolanon (University of Copenhagen, Denmark) who kindly supplied Nod factor preparations. We thank M. Poulsen for the experimental support. This work was supported by the Danish National Research Foundation (grant no. DNRF79) and the ERC (advanced grant 268523).

\section{LITERATURE CITED}

Afonso-Grunz, F., Molina, C., Hoffmeier, K., Rycak, L., Kudapa, H., Varshney, R. K., Drevon, J. J., Winter, P., and Kahl, G. 2014. Genomebased analysis of the transcriptome from mature chickpea root nodules. Front. Plant Sci. 5:325. 
Andriankaja, A., Boisson-Dernier, A., Frances, L., Sauviac, L., Jauneau, A., Barker, D. G., and de Carvalho-Niebel, F. 2007. AP2-ERF transcription factors mediate Nod factor dependent Mt ENOD11 activation in root hairs via a novel cis-regulatory motif. Plant Cell 19:2866-2885.

Antolín-Llovera, M., Ried, M. K., and Parniske, M. 2014. Cleavage of the SYMBIOSIS RECEPTOR-LIKE KINASE ectodomain promotes complex formation with Nod factor receptor 5. Curr. Biol. 24:422-427.

Asamizu, E., Shimoda, Y., Kouchi, H., Tabata, S., and Sato, S. 2008. A positive regulatory role for $L j E R F 1$ in the nodulation process is revealed by systematic analysis of nodule-associated transcription factors of Lotus japonicus. Plant Physiol. 147:2030-2040.

Broghammer, A., Krusell, L., Blaise, M., Sauer, J., Sullivan, J. T., Maolanon, N., Vinther, M., Lorentzen, A., Madsen, E. B., Jensen, K. J., Roepstorff, P., Thirup, S., Ronson, C. W., Thygesen, M. B., and Stougaard, J. 2012. Legume receptors perceive the rhizobial lipochitin oligosaccharide signal molecules by direct binding. Proc. Natl. Acad. Sci. U.S.A. 109:13859-13864.

Cerri, M. R., Frances, L., Laloum, T., Auriac, M. C., Niebel, A., Oldroyd, G. E., Barker, D. G., Fournier, J., and de Carvalho-Niebel, F. 2012 Medicago truncatula ERN transcription factors: Regulatory interplay with NSP1/NSP2 GRAS factors and expression dynamics throughout rhizobial infection. Plant Physiol. 160:2155-2172.

Cerri, M. R., Frances, L., Kelner, A., Fournier, J., Middleton, P. H., Auriac, M. C., Mysore, K. S., Wen, J., Erard, M., Barker, D. G., Oldroyd, G. E., and de Carvalho-Niebel, F. 2016. The symbiosis-related ERN transcription factors act in concert to coordinate rhizobial host root infection Plant Physiol. 171:1037-1054.

Colebatch, G., Desbrosses, G., Ott, T., Krusell, L., Montanari, O., Kloska S., Kopka, J., and Udvardi, M. K. 2004. Global changes in transcription orchestrate metabolic differentiation during symbiotic nitrogen fixation in Lotus japonicus. Plant J. 39:487-512.

Ferguson, B. J., Indrasumunar, A., Hayashi, S., Lin, M. H., Lin, Y. H., Reid, D. E., and Gresshoff, P. M. 2010. Molecular analysis of legume nodule development and autoregulation. J. Integr. Plant Biol. 52:61-76.

Fournier, J., Teillet, A., Chabaud, M., Ivanov, S., Genre, A., Limpens, E., de Carvalho-Niebel, F., and Barker, D. G. 2015. Remodeling of the infection chamber before infection thread formation reveals a two-step mechanism for rhizobial entry into the host legume root hair. Plant Physiol. 167:1233-1242.

Fukai, E., Soyano, T., Umehara, Y., Nakayama, S., Hirakawa, H., Tabata, S., Sato, S., and Hayashi, M. 2012. Establishment of a Lotus japonicus gene tagging population using the exon-targeting endogenous retrotransposon LORE1. Plant J. 69:720-730.

Giovannetti, M., Ayio, L., Sbrana, C., and Silvia Citernesi, A. 1993. Factors affecting appressorium development in the vesicular-arbuscular mycorrhizal fungus Glomus mosseae (Nicol. \& Gerd.) Gerd. \& Trappe. New Phytol. 123:115-122.

Godiard, L., Lepage, A., Moreau, S., Laporte, D., Verdenaud, M., Timmers, T., and Gamas, P. 2011. MtbHLH1, a bHLH transcription factor involved in Medicago truncatula nodule vascular patterning and nodule to plant metabolic exchanges. New Phytol. 191:391-404.

Handa, Y., Nishide, H., Takeda, N., Suzuki, Y., Kawaguchi, M., and Saito, K. 2015. RNA-seq transcriptional profiling of an arbuscular mycorrhiza provides insights into regulated and coordinated gene expression in Lotus japonicus and Rhizophagus irregularis. Plant Cell Physiol. 56: 1490-1511.

Handberg, K., and Stougaard, J. 1992. Lotus japonicus, an autogamous, diploid legume species for classical and molecular genetics. Plant J. 2:487-496.

Hansen, J., Jorgensen, J. E., Stougaard, J., and Marcker, K. A. 1989. Hairy roots - a short cut to transgenic root nodules. Plant Cell Rep. 8:12-15.

Heckmann, A. B., Lombardo, F., Miwa, H., Perry, J. A., Bunnewell, S., Parniske, M., Wang, T. L., and Downie, J. A. 2006. Lotus japonicus nodulation requires two GRAS domain regulators, one of which is functionally conserved in a non-legume. Plant Physiol. 142:1739-1750.

Heckmann, A. B., Sandal, N., Bek, A. S., Madsen, L. H., Jurkiewicz, A., Nielsen, M. W., Tirichine, L., and Stougaard, J. 2011. Cytokinin induction of root nodule primordia in Lotus japonicus is regulated by a mechanism operating in the root cortex. Mol. Plant-Microbe Interact 24:1385-1395.

Hirota, A., Kato, T., Fukaki, H., Aida, M., and Tasaka, M. 2007. The auxinregulated AP2/EREBP gene $P U C H I$ is required for morphogenesis in the early lateral root primordium of Arabidopsis. Plant Cell 19:21562168.

Hirsch, S., Kim, J., Munoz, A., Heckmann, A. B., Downie, J. A., and Oldroyd, G. E. 2009. GRAS proteins form a DNA binding complex to induce gene expression during nodulation signaling in Medicago truncatula. Plant Cell 21:545-557.
Hogekamp, C., and Kuster, H. 2013. A roadmap of cell-type specific gene expression during sequential stages of the arbuscular mycorrhiza symbiosis. BMC Genomics 14:306.

Hogekamp, C., Arndt, D., Pereira, P. A., Becker, J. D., Hohnjec, N., and Kuster, H. 2011. Laser microdissection unravels cell-type-specific transcription in arbuscular mycorrhizal roots, including CAAT-box transcription factor gene expression correlating with fungal contact and spread. Plant Physiol. 157:2023-2043.

Høgslund, N., Radutoiu, S., Krusell, L., Voroshilova, V., Hannah, M. A., Goffard, N., Sanchez, D. H., Lippold, F., Ott, T., Sato, S., Tabata, S., Liboriussen, P., Lohmann, G. V., Schauser, L., Weiller, G. F., Udvardi, M. K., and Stougaard, J. 2009a. Dissection of symbiosis and organ development by integrated transcriptome analysis of lotus japonicus mutant and wild-type plants. PLoS One 4:e6556.

Holt, D. B., Gupta, V., Meyer, D., Abel, N. B., Andersen, S. U., Stougaard, J., and Markmann, K. 2015. Micro RNA 172 (miR172) signals epidermal infection and is expressed in cells primed for bacterial invasion in Lotus japonicus roots and nodules. New Phytol. 208:241-256.

Huang, P. Y., Catinot, J., and Zimmerli, L. 2016. Ethylene response factors in Arabidopsis immunity. J. Exp. Bot. 67:1231-1241.

Kaneko, T., Nakamura, Y., Sato, S., Asamizu, E., Kato, T., Sasamoto, S., Watanabe, A., Idesawa, K., Ishikawa, A., Kawashima, K., Kimura, T., Kishida, Y., Kiyokawa, C., Kohara, M., Matsumoto, M., Matsuno, A. Mochizuki, Y., Nakayama, S., Nakazaki, N., Shimpo, S., Sugimoto, M. Takeuchi, C., Yamada, M., and Tabata, S. 2000. Complete genome structure of the nitrogen-fixing symbiotic bacterium Mesorhizobium loti. DNA Res. 7:331-338.

Kang, H., Chu, X., Wang, C., Xiao, A., Zhu, H., Yuan, S., Yang, Z., Ke, D., Xiao, S., Hong, Z., and Zhang, Z. 2014. A MYB coiled-coil transcription factor interacts with NSP2 and is involved in nodulation in Lotus japonicus. New Phytol. 201:837-849.

Kawaharada, Y., Kelly, S., Nielsen, M. W., Hjuler, C. T., Gysel, K., Muszynski, A., Carlson, R. W., Thygesen, M. B., Sandal, N., Asmussen, M. H., Vinther, M., Andersen, S. U., Krusell, L., Thirup, S., Jensen, K. J., Ronson, C. W., Blaise, M., Radutoiu, S., and Stougaard, J. 2015. Receptor-mediated exopolysaccharide perception controls bacterial infection. Nature 523:308-312.

Kawaharada, Y., Nielsen, M. W., Kelly, S., James, E. K., Andersen, K. R., Rasmussen, S. R., Füchtbauer, W., Madsen, L. H., Heckmann, A. B., Radutoiu, S., and Stougaard, J. 2017. Differential regulation of the Epr3 receptor coordinates membrane-restricted rhizobial colonization of root nodule primordia. Nat. Commun. Published online. DOI: $10.1038 /$ ncomms 14534

Kazusa DNA Research Institute, The Cold Spring Harbor and Washington University Sequencing Consortium, The European Union Arabidopsis Genome Sequencing Consortium, and Institute of Plant Genetics and Crop Plant Research (IPK). 2000. Sequence and analysis of chromosome 5 of the plant Arabidopsis thaliana. Nature 408:823-826.

Kelly, S. J., Muszynski, A., Kawaharada, Y., Hubber, A. M., Sullivan, J. T. Sandal, N., Carlson, R. W., Stougaard, J., and Ronson, C. W. 2013. Conditional requirement for exopolysaccharide in the MesorhizobiumLotus symbiosis. Mol. Plant-Microbe Interact 26:319-329.

Kelly, S., Sullivan, J., Ronson, C., Tian, R., Brau, L., Munk, C., Goodwin, L., Han, C., Woyke, T., Reddy, T., Huntemann, M., Pati, A., Mavromatis, K., Markowitz, V., Ivanova, N., Kyrpides, N., and Reeve, W. 2014. Genome sequence of the Lotus spp. microsymbiont Mesorhizobium loti strain R7A. Stand. Genomic Sci. 9:6.

Kim, M. J., Ruzicka, D., Shin, R., and Schachtman, D. P. 2012. The Arabidopsis AP2/ERF transcription factor RAP2.11 modulates plant response to low-potassium conditions. Mol. Plant 5:1042-1057.

Kouchi, H., Imaizumi-Anraku, H., Hayashi, M., Hakoyama, T., Nakagawa, T., Umehara, Y., Suganuma, N., and Kawaguchi, M. 2010. How many peas in a pod? Legume genes responsible for mutualistic symbioses underground. Plant Cell Physiol. 51:1381-1397.

Laloum, T., Baudin, M., Frances, L., Lepage, A., Billault-Penneteau, B., Cerri, M. R., Ariel, F., Jardinaud, M.-F., Gamas, P., de Carvalho-Niebel, F., and Niebel, A. 2014. Two CCAAT-box-binding transcription factors redundantly regulate early steps of the legume-rhizobia endosymbiosis. Plant J. 79:757-768.

Libault, M., Joshi, T., Takahashi, K., Hurley-Sommer, A., Puricelli, K. Blake, S., Finger, R. E., Taylor, C. G., Xu, D., Nguyen, H. T., and Stacey, G. 2009. Large-scale analysis of putative soybean regulatory gene expression identifies a $M y b$ gene involved in soybean nodule development. Plant Physiol. 151:1207-1220.

Madsen, E. B., Madsen, L. H., Radutoiu, S., Olbryt, M., Rakwalska, M., Szczyglowski, K., Sato, S., Kaneko, T., Tabata, S., Sandal, N., and Stougaard, J. 2003. A receptor kinase gene of the LysM type is involved in legume perception of rhizobial signals. Nature 425:637-640. 
Madsen, L. H., Fukai, E., Radutoiu, S., Yost, C. K., Sandal, N., Schauser, L., and Stougaard, J. 2005. LORE1, an active low-copy-number TY3-gypsy retrotransposon family in the model legume Lotus japonicus. Plant J. 44:372-381.

Madsen, L. H., Tirichine, L., Jurkiewicz, A., Sullivan, J. T., Heckmann, A. B., Bek, A. S., Ronson, C. W., James, E. K., and Stougaard, J. 2010. The molecular network governing nodule organogenesis and infection in the model legume Lotus japonicus. Nat. Commun. 1:10.

Madsen, E. B., Antolín-Llovera, M., Grossmann, C., Ye, J., Vieweg, S., Broghammer, A., Krusell, L., Radutoiu, S., Jensen, O. N., Stougaard, J., and Parniske, M. 2011. Autophosphorylation is essential for the in vivo function of the Lotus japonicus Nod factor receptor 1 and receptormediated signalling in cooperation with Nod factor receptor 5. Plant J. 65:404-417.

Maekawa, T., Kusakabe, M., Shimoda, Y., Sato, S., Tabata, S., Murooka, Y., and Hayashi, M. 2008. Polyubiquitin promoter-based binary vectors for overexpression and gene silencing in Lotus japonicus. Mol. PlantMicrobe Interact 21:375-382

Maekawa, T., Maekawa-Yoshikawa, M., Takeda, N., Imaizumi-Anraku, H., Murooka, Y., and Hayashi, M. 2009. Gibberellin controls the nodulation signaling pathway in Lotus japonicus. Plant J. 58:183-194.

Malolepszy, A., Urbański, D. F., James, E. K., Sandal, N., Isono, E., Stougaard, J., and Andersen, S. U. 2015. The deubiquitinating enzyme AMSH1 is required for rhizobial infection and nodule organogenesis in Lotus japonicus. Plant J. 83:719-731.

Małolepszy, A., Mun, T., Sandal, N., Gupta, V., Dubin, M., Urbański, D., Shah, N., Bachmann, A., Fukai, E., Hirakawa, H., Tabata, S., Nadzieja, M., Markmann, K., Su, J., Umehara, Y., Soyano, T., Miyahara, A., Sato, S., Hayashi, M., Stougaard, J., and Andersen, S. U. 2016. The LORE1 insertion mutant resource. Plant J. 88:306-317.

Martínez-Romero, E. 2003. Diversity of Rhizobium-Phaseolus vulgaris symbiosis: Overview and perspectives. Plant Soil 252:11-23.

Mbengue, M., Camut, S., de Carvalho-Niebel, F., Deslandes, L., Froidure, S., Klaus-Heisen, D., Moreau, S., Rivas, S., Timmers, T., Herve, C., Cullimore, J., and Lefebvre, B. 2010. The Medicago truncatula E3 ubiquitin ligase PUB1 interacts with the LYK3 symbiotic receptor and negatively regulates infection and nodulation. Plant Cell 22:3474-3488.

Middleton, P. H., Jakab, J., Penmetsa, R. V., Starker, C. G., Doll, J., Kalo, P. Prabhu, R., Marsh, J. F., Mitra, R. M., Kereszt, A., Dudas, B., VandenBosch, K., Long, S. R., Cook, D. R., Kiss, G. B., and Oldroyd, G. E. 2007. An ERF transcription factor in Medicago truncatula that is essential for Nod factor signal transduction. Plant Cell 19:1221-1234.

Miller, J. B., Pratap, A., Miyahara, A., Zhou, L., Bornemann, S., Morris, R. J., and Oldroyd, G. E. 2013. Calcium/calmodulin-dependent protein kinase is negatively and positively regulated by calcium, providing a mechanism for decoding calcium responses during symbiosis signaling. Plant Cell 25:5053-5066.

Miwa, H., Sun, J., Oldroyd, G. E., and Downie, J. A. 2006. Analysis of Nodfactor-induced calcium signaling in root hairs of symbiotically defective mutants of Lotus japonicus. Mol. Plant-Microbe Interact 19:914-923.

Nova-Franco, B., Iniguez, L. P., Valdes-Lopez, O., Alvarado-Affantranger, X., Leija, A., Fuentes, S. I., Ramirez, M., Paul, S., Reyes, J. L., Girard, L., and Hernandez, G. 2015. The micro-RNA72c-APETALA2-1 node as a key regulator of the common bean-Rhizobium etli nitrogen fixation symbiosis. Plant Physiol. 168:273-291.

Nukui, N., Ezura, H., Yuhashi, K., Yasuta, T., and Minamisawa, K. 2000. Effects of ethylene precursor and inhibitors for ethylene biosynthesis and perception on nodulation in Lotus japonicus and Macroptilium atropurpureum. Plant Cell Physiol. 41:893-897.

Oldroyd, G. E. 2013. Speak, friend, and enter: Signalling systems that promote beneficial symbiotic associations in plants. Nat. Rev. Microbiol. $11: 252-263$

Petit, A., Stougaard, J., Kühle, A., Marcker, K., and Tempé, J. 1987. Transformation and regeneration of the legume Lotus corniculatus: A system for molecular studies of symbiotic nitrogen fixation. Mol. Gen. Genet. 207:245-250.

Radutoiu, S., Madsen, L. H., Madsen, E. B., Felle, H. H., Umehara, Y., Gronlund, M., Sato, S., Nakamura, Y., Tabata, S., Sandal, N., and Stougaard, J. 2003. Plant recognition of symbiotic bacteria requires two LysM receptor-like kinases. Nature 425:585-592.

Schauser, L., Roussis, A., Stiller, J., and Stougaard, J. 1999. A plant regulator controlling development of symbiotic root nodules. Nature 402:191-195.

Schauser, L., Wieloch, W., and Stougaard, J. 2005. Evolution of NIN-like proteins in Arabidopsis, rice, and Lotus japonicus. J. Mol. Evol. 60: 229-237.

Shimada, N., Aoki, T., Sato, S., Nakamura, Y., Tabata, S., and Ayabe, S. 2003. A cluster of genes encodes the two types of chalcone isomerase involved in the biosynthesis of general flavonoids and legume-specific 5-deoxy(iso)flavonoids in Lotus japonicus. Plant Physiol. 131:941-951. Shimoda, Y., Han, L., Yamazaki, T., Suzuki, R., Hayashi, M., and Imaizumi-Anraku, H. 2012. Rhizobial and fungal symbioses show different requirements for calmodulin binding to calcium calmodulindependent protein kinase in Lotus japonicus. Plant Cell 24:304-321.

Singh, S., Katzer, K., Lambert, J., Cerri, M., and Parniske, M. 2014 CYCLOPS, a DNA-binding transcriptional activator, orchestrates symbiotic root nodule development. Cell Host Microbe 15:139-152.

Sinharoy, S., Torres-Jerez, I., Bandyopadhyay, K., Kereszt, A., Pislariu, C. I., Nakashima, J., Benedito, V. A., Kondorosi, E., and Udvardi, M. K 2013. The $\mathrm{C} 2 \mathrm{H} 2$ transcription factor regulator of symbiosome differentiation represses transcription of the secretory pathway gene VAMP721a and promotes symbiosome development in Medicago truncatula. Plant Cell 25:3584-3601.

Soyano, T., and Hayashi, M. 2014. Transcriptional networks leading to symbiotic nodule organogenesis. Curr. Opin. Plant Biol. 20:146-154.

Soyano, T., Kouchi, H., Hirota, A., and Hayashi, M. 2013. Nodule inception directly targets NF-Y subunit genes to regulate essential processes of root nodule development in Lotus japonicus. PLoS Genet. 9:e1003352.

Stougaard, J., Abildsten, D., and Marcker, K. 1987. The Agrobacterium rhizogenes $\mathrm{pRi}$ TL-DNA segment as a gene vector system for transformation of plants. Mol. Gen. Genet. 207:251-255.

Takeda, N., Tsuzuki, S., Suzaki, T., Parniske, M., and Kawaguchi, M. 2013. CERBERUS and NSP1 of Lotus japonicus are common symbiosis genes that modulate arbuscular mycorrhiza development. Plant Cell Physiol. 54:1711-1723.

Tirichine, L., James, E. K., Sandal, N., and Stougaard, J. 2006. Spontaneous root-nodule formation in the model legume Lotus japonicus: A novel class of mutants nodulates in the absence of rhizobia. Mol. PlantMicrobe Interact 19:373-382.

Trujillo, D. I., Silverstein, K. A., and Young, N. D. 2014. Genomic characterization of the LEED.PEEDs, a gene family unique to the Medicago lineage. G3 (Bethesda) 4:2003-2012.

Urbański, D. F., Malolepszy, A., Stougaard, J., and Andersen, S. U. 2012. Genome-wide LORE1 retrotransposon mutagenesis and high-throughput insertion detection in Lotus japonicus. Plant J. 69:731-741.

Vanneste, K., Maere, S., and Van de Peer, Y. 2014. Tangled up in two: A burst of genome duplications at the end of the Cretaceous and the consequences for plant evolution. Philos. Trans. R. Soc. Lond. B Biol. Sci. 369.

Verdier, J., Torres-Jerez, I., Wang, M., Andriankaja, A., Allen, S. N., He, J., Tang, Y., Murray, J. D., and Udvardi, M. K. 2013. Establishment of the Lotus japonicus Gene Expression Atlas (LjGEA) and its use to explore legume seed maturation. Plant J. 74:351-362.

Vernié, T., Moreau, S., de Billy, F., Plet, J., Combier, J. P., Rogers, C., Oldroyd, G., Frugier, F., Niebel, A., and Gamas, P. 2008. EFD Is an ERF transcription factor involved in the control of nodule number and differentiation in Medicago truncatula. Plant Cell 20: 2696-2713.

Vernié, T., Kim, J., Frances, L., Ding, Y., Sun, J., Guan, D., Niebel, A., Gifford, M. L., de Carvalho-Niebel, F., and Oldroyd, G. E. 2015. The NIN transcription factor coordinates diverse nodulation programs in different tissues of the Medicago truncatula root. Plant Cell 27: 3410-3424

Wang, Y., Wang, L., Zou, Y., Chen, L., Cai, Z., Zhang, S., Zhao, F., Tian, Y., Jiang, Q., Ferguson, B. J., Gresshoff, P. M., and Li, X. 2014. Soybean miR172c targets the repressive AP2 transcription factor $\mathrm{NNC} 1$ to activate ENOD40 expression and regulate nodule initiation. Plant Cell 26:4782-4801.

Webb, K. J., Cookson, A., Allison, G., Sullivan, M. L., and Winters, A. L. 2013. Gene expression patterns, localization, and substrates of polyphenol oxidase in red clover (Trifolium pratense L.). J. Agric. Food Chem. 61:7421-7430.

Yan, Z., Hossain, M. S., Wang, J., Valdes-Lopez, O., Liang, Y., Libault, M., Qiu, L., and Stacey, G. 2013. miR172 regulates soybean nodulation. Mol. Plant-Microbe Interact 26:1371-1377.

Yano, K., Yoshida, S., Muller, J., Singh, S., Banba, M., Vickers, K. Markmann, K., White, C., Schuller, B., Sato, S., Asamizu, E., Tabata, S. Murooka, Y., Perry, J., Wang, T. L., Kawaguchi, M., Imaizumi-Anraku, H., Hayashi, M., and Parniske, M. 2008. CYCLOPS, a mediator of symbiotic intracellular accommodation. Proc. Natl. Acad. Sci. U.S.A. 105:20540-20545.

Yano, K., Shibata, S., Chen, W. L., Sato, S., Kaneko, T., Jurkiewicz, A., Sandal, N., Banba, M., Imaizumi-Anraku, H., Kojima, T., Ohtomo, R., Szczyglowski, K., Stougaard, J., Tabata, S., Hayashi, M., Kouchi, H., and Umehara, Y. 2009. CERBERUS, a novel U-box protein containing WD-40 repeats, is required for formation of the infection thread and 
nodule development in the legume-Rhizobium symbiosis. Plant J. 60: 168-180.

Yokota, K., Fukai, E., Madsen, L. H., Jurkiewicz, A., Rueda, P., Radutoiu, S., Held, M., Hossain, M. S., Szczyglowski, K., Morieri, G., Oldroyd, G. E., Downie, J. A., Nielsen, M. W., Rusek, A. M., Sato, S., Tabata, S., James, E. K., Oyaizu, H., Sandal, N., and Stougaard, J. 2009. Rearrangement of actin cytoskeleton mediates invasion of Lotus japonicus roots by Mesorhizobium loti. Plant Cell 21:267-284.

Yoro, E., Suzaki, T., Toyokura, K., Miyazawa, H., Fukaki, H., and Kawaguchi, M. 2014. A positive regulator of nodule organogenesis, NODULE INCEPTION, acts as a negative regulator of rhizobial infection in Lotus japonicus. Plant Physiol. 165:747-758.

Young, N. D., Debelle, F., Oldroyd, G. E., Geurts, R., Cannon, S. B., Udvardi, M. K., Benedito, V. A., Mayer, K. F., Gouzy, J., Schoof, H., Van de Peer, Y., Proost, S., Cook, D. R., Meyers, B. C., Spannagl, M., Cheung, F., De Mita, S., Krishnakumar, V., Gundlach, H., Zhou, S., Mudge, J., Bharti, A. K., Murray, J. D., Naoumkina, M. A., Rosen, B., Silverstein, K. A., Tang, H., Rombauts, S., Zhao, P. X., Zhou, P., Barbe, V., Bardou, P., Bechner, M., Bellec, A., Berger, A., Berges, H., Bidwell, S., Bisseling, T., Choisne, N., Couloux, A., Denny, R., Deshpande, S., Dai, X., Doyle, J. J., Dudez, A. M., Farmer, A. D., Fouteau, S., Franken,
C., Gibelin, C., Gish, J., Goldstein, S., Gonzalez, A. J., Green, P. J., Hallab, A., Hartog, M., Hua, A., Humphray, S. J., Jeong, D. H., Jing, Y., Jocker, A., Kenton, S. M., Kim, D. J., Klee, K., Lai, H., Lang, C., Lin, S., Macmil, S. L., Magdelenat, G., Matthews, L., McCorrison, J., Monaghan, E. L., Mun, J. H., Najar, F. Z., Nicholson, C., Noirot, C., O’Bleness, M., Paule, C. R., Poulain, J., Prion, F., Qin, B., Qu, C., Retzel, E. F., Riddle, C., Sallet, E., Samain, S., Samson, N., Sanders, I., Saurat, O., Scarpelli, C., Schiex, T., Segurens, B., Severin, A. J., Sherrier, D. J., Shi, R., Sims, S., Singer, S. R., Sinharoy, S., Sterck, L., Viollet, A., Wang, B. B., Wang, K., Wang, M., Wang, X., Warfsmann, J., Weissenbach, J., White, D. D., White, J. D., Wiley, G. B., Wincker, P., Xing, Y., Yang, L., Yao, Z., Ying, F., Zhai, J., Zhou, L., Zuber, A., Denarie, J., Dixon, R. A., May, G. D., Schwartz, D. C., Rogers, J., Quetier, F., Town, C. D., and Roe, B. A. 2011. The Medicago genome provides insight into the evolution of rhizobial symbioses. Nature 480: 520-524.

\section{AUTHOR-RECOMMENDED INTERNET RESOURCE}

Lotus Base database: https://lotus.au.dk 